\title{
Detection of Viruses Infecting Stone Fruits in Western Mediterranean Region of Turkey
}

\author{
Bayram Çevik Nejla Yardimci and Handan Çulal-Kılıç \\ Department of Plant Protection, Faculty of Agriculture, Suleyman Demirel University 32260 Isparta, Turkey \\ (Received on October 2, 2010; Accepted on February 8, 2011)
}

Field surveys were conducted in 45 stone fruit orchards in seven districts of Isparta Province located in western Mediterranean region of Turkey important for stone fruit production. Leaf samples were collected from 175 trees showing virus-like symptoms. These samples were first tested by ELISA for five different RNA viruses including Apple mosaic ilarvirus (ApMV), Prunus necrotic ringspot ilarvirus (PNRSV), Prune dwarf ilarvirus (PDV), Plum pox potyvirus (PPV), Apple chlorotic leafspot trichovirus (ACLSV). While no ApMV and PPV infection was found, 46, 24 and 16 samples were tested positive for PDV, ACLSV and PNRSV, respectively, in ELISA showing about $45 \%$ of symptomatic trees in the region were infected with at least one of these viruses. In addition, it was found that nine sweet cherry trees were mixed infected with two or three of these viruses and PDV with an infection rate of $26.3 \%$ was the most widespread virus in symptomatic trees in western Mediterranean region. Thirty samples were selected and tested by a multiplex RT-PCR (mRT-PCR) for simultaneous detection of these viruses. While PPV was not detected, more than half of the tested 20 samples were individually or mixed infected with ApMV, ACLSV, PNRSV and PDV. The mRT-PCR results were confirmed by detection of these viruses individually in some of the field samples using RT-PCR with primes specific to each virus. Comparison of ELSA and $m R T-P C R$ results of 30 samples showed that numbers of infected and mixed infected samples as well as infection and mixed infection rates were significantly higher in RT-PCR (20 and 66.7\%) than in ELISA (14 and 46.7\%). The results confirm that mRT-PCR is more sensitive than ELISA.

Keywords : ELISA, multiplex RT-PCR, RNA viruses, stone fruits, virus detection

A large number of RNA viruses cause economically important diseases on stone fruits worldwide (Dunez, 1988; Myrta et al., 2003; Nemat, 1986). Most of these viruses are

\footnotetext{
*Corresponding author.

Phone) +902462114737, FAX) +902462371693

E-mail)bcevik@ziraat.sdu.edu.tr
}

biologically and taxonomically different and belong to different genera of single strand positive sense RNA viruses. The most common RNA viruses found in stone fruits include Apple mosaic ilarvirus (ApMV), Prunus necrotic ringspot ilarvirus (PNRSV), Prune dwarfilarvirus (PDV), Plum pox potyvirus (PPV), and Apple chlorotic leafspot trichovirus (ACLSV). These viruses are widely distributed in stone fruit production areas of the world and some of them found with infection rate of $25-100 \%$ in certain regions of the Mediterranean basin (Myrta et al., 2003). Frequent mixed infections with two or more of these viruses ranging from 8 to $22 \%$ were observed in some orchards. Combination of high infection rate and frequent mixed infections causes significant yield reduction up to $57 \%$ and economical losses in some region (Dominguez et al., 1998; Myrta et al., 2003; Varveri and Bem, 1995).

Stone fruit trees were mainly tested for virus infection by serological methods, especially by ELISA. Even though ELISA is a reliable test appropriate for routine diagnostic screening, it has low sensitivity and pathogens present at very low titer may not be detected. Therefore, nucleic acid methods such as RT-PCR, hybridization and combination of RT-PCR and ELISA were developed (Herranz et al., 2005; Pallas et al., 1998; Sanchez-Navaro et al., 1998; Saade et al., 2000). More recently multiplex RT-PCR (mRT-PCR) method enabling simultaneous detection of multiple viruses have been developed and become a desirable assay for routine diagnostic tests because it is more sensitive and require less time, labor and cost (Hassan et al., 2006; Menzel et al., 2002; Sanchez-Navaro et al., 2005). A mRT-PCR assay was developed for simultaneous detection of eight different stone fruit viruses including ApMV, ACLSV, PNRSV, PDV, PPV, ApLV, APLPV and PBNSPaV. The method was successfully used for detection of these viruses on stone fruit trees in the field (Sanchez-Navarro et al., 2005).

Presence of stone fruit viruses has previously been reported in Turkey. ApMV, ACLSV, PNRSV, PDV and PPV commonly found in commercial orchards in different stone fruit growing regions including Aegean (Azeri, unpublished data), eastern Mediterranean (Gazel and Çaglayan, unpublished 
data; Yildizgördü Çali, unpublished data), eastern Anatolian (Elibüyük and Erdiler, 1998; Sipahioglu et al., 1999; Sipahioglu and Baloglu, unpublished data), central Anatolian (Elibüyük, 2003) regions. Some of these viruses were also found nurseries in certain regions (Sertkaya et al., 2004; Ulubaș and Ertunç, 2004). In addition, mixed infection of two or more of these viruses were detected in some regions by ELISA.

Isparta Province located in the western Mediterranean region of Turkey is an important fruit production region. However, presence of viruses on stone fruits is largely unknown in the region. So far only one study was conducted for attempting to determine presence of stone fruit viruses in Isparta. As part of a national survey 16 stone fruit samples from a collection orchard in Isparta were tested for ACLSV and PNRSV. Only one sample was tested positive for ACLSV by ELISA (Ulubaş and Ertunç, 2005) and one peach and plum tree were found to be infected with PNRSV by RT-PCR in the collection orchard (Ulubas and Ertunç, 2004). In a regional survey, ApMV was detected on apple orchards in Isparta (Yardimci and Eryigit, 2005). However, no comprehensive surveys and tests were conducted in the region to detect stone fruit viruses in commercial orchards. In this study, stone fruit orchards were screened for five different RNA viruses including ACLSV, ApMV, PDV, PNRSV and PPV by serological and molecular assays. Infection rate of these viruses in symptomatic trees in different locations and different Prunus hosts was determined. In addition, the sensitivity of ELISA and mRTPCR was compared for evaluation of different detection assays for virus screening on stone fruits in Isparta.

\section{Materials and Methods}

Field surveys. Surveys were conducted in spring of 2005 in a number of commercial and one collection stone fruit orchards in nine different districts of Isparta Province located in south-western Turkey. Leaf samples were collected from a total of 175 different stone fruit trees including sweet cherry, sour cherry, peach, apricot and plum showing virus or virus-like symptoms. Locations and the hosts of 175 samples collected during field surveys are shown in Table 2.

Double antibody sandwich enzyme linked immunosorbent assay (DAS-ELISA). All leaf samples were tested for the presence of five different RNA viruses infecting stone fruits including ACLSV, ApMV, PNRSV, PDV and PPP by enzyme linked immunosorbent assay (ELISA) using specific ELISA detection kits for respective viruses (Agdia, Elkhart, USA) based on previously reported DASELISA method (Clark and Adams, 1977) with alkaline phosphatase. Absorbance values of alkaline phosphatase were measured at $405 \mathrm{~nm}$ with VersaMax microplate reader (Molecular Devices, Sunnyvale, CA). Samples with absorbance values greater than twice the mean absorbance reading of healthy controls obtained from Agdia (Elkhart, USA) were considered positive for each virus.

Nucleic acid isolation. Different nucleic acid isolation methods were used for isolation of total nucleic acid and dsRNA. Total nucleic acids were isolated from stone fruit leaf samples using previously published methods (Astruc et el., 1996) with minor modifications. About $100 \mathrm{mg}$ leaf tissue was first grounded with liquid nitrogen in $2 \mathrm{ml}$ tube with plastic passel attached to hand held drill and homogenized in $1 \mathrm{ml}$ of extraction buffer (100 mM Tris- $\mathrm{HCl}, 50$ mM EDTA, pH 8.0, $500 \mathrm{mM} \mathrm{NaCl}, 10 \mathrm{mM} \beta$-mercaptoethanol). After the addition of $50 \mathrm{ml}$ of $20 \% \mathrm{SDS}$ the homogenate was incubated at $65^{\circ} \mathrm{C}$ for $20 \mathrm{~min}$. Then, 250 $\mathrm{ml}$ of $5 \mathrm{M} \mathrm{KOAc}$ were added and the mixture was incubated on ice for $20 \mathrm{~min}$. After the removal of unwanted plant debris by centrifugation at $10,000 \mathrm{rpm}$ for $15 \mathrm{~min}$ at $4{ }^{\circ} \mathrm{C}$, nucleic acids were recovered from the supernatant by ethanol precipitation. It was washed with $70 \%$ cold ethanol, air dried, resuspended in $50 \mathrm{ml}$ of sterile water and stored at $-80^{\circ} \mathrm{C}$.

A previously reported dsRNA isolation method (Morris and Dodds, 1979) was modified and used for dsRNA isolation from some samples from which RNA was not recovered by total nucleic isolation protocol described above. Briefly, about $5 \mathrm{~g}$ leave tissue were first ground in a mortar and homogenized in $10 \mathrm{ml}$ of STE buffer $(0.1 \mathrm{M}$ $\mathrm{NaCl}, 0.05 \mathrm{M}$ Tris - $\mathrm{HCl}, 0.1 \mathrm{mM}$ EDTA, pH 6.8), then mixed with $10 \mathrm{ml}$ phenol, chloroform-pentanol (25:1 v:v), with $2 \%$ bentonit and $10 \%$ SDS. The mixture was centrifuged at 10,000 rpm for $20 \mathrm{~min}, 95 \%$ ethanol was added into the supernatant and after overnight incubation at $4{ }^{\circ} \mathrm{C}$ it was fractionated on Whatman CF-11 cellulose columns in the presence of ethanol to select dsRNA. Then, dsRNAs bound cellulose columns were eluted from the cellulose in ethanol free STE buffer, concentrated by ethanol precipitation, resuspended in $50 \mu 1$ sterile water and stored at $-80^{\circ} \mathrm{C}$.

Multiplex reverse transcription polymerase chain reaction (mRT-PCR). The mRT-PCR method previously reported for simultaneous detection of eight different stone fruit viruses was modified and used for detection of five viruses including ACLSV, ApMV, PDV, PPV and PNRSV in this study using primers listed in Table 1 . About 1-5 $\mu$ l of total nucleic acids or dsRNA from the different extraction procedures were denatured by incubation at $70^{\circ} \mathrm{C}$ or $95^{\circ} \mathrm{C}$ for 5 min and used to perform a $25 \mu \mathrm{lmRT}$-PCR reaction using MMuLV reverse transcriptase (Biobasic, Canada) and Taq 
Table 1. The list of primers used for detection of stone fruit viruses

\begin{tabular}{|c|c|c|c|c|}
\hline Primer code & Virus & Oriantation & Sequence* & Product size (bp) \\
\hline BC 1 & \multirow{2}{*}{ ACLSV } & Antisense & 5' TGCCGTCCCGATTAGGTTG 3' & \multirow{2}{*}{632} \\
\hline BC 2 & & Sense & 5' CCATCTTCGCGAACATAGC 3' & \\
\hline BC 3 & \multirow{2}{*}{ ApMV } & Antisense & 5' CGTGAGGAAGTTTAGGTTG 3' & \multirow{2}{*}{417} \\
\hline $\mathrm{BC} 4$ & & Sense & 5' GCCTCCTAATCGGGGCATCAA 3' & \\
\hline BC 5 & \multirow{2}{*}{ PDV } & Antisense & 5' CAACGTAGGAAGTTCACAG 3' & \multirow{2}{*}{517} \\
\hline BC 6 & & Sense & 5' GCATCCCTTAAAGGGGCATC 3' & \\
\hline $\mathrm{BC} 7$ & \multirow{2}{*}{ PNRSV } & Antisense & 5' GAACCTCCTTCCGATTTAG 3' & \multirow{2}{*}{346} \\
\hline BC 8 & & Sense & 5' GCTTCCCTAACGGGGCATCCAC 3' & \\
\hline BC 9 & \multirow{2}{*}{ PPV } & Antisense & 5' CAATAAAGCCATTGTTGGATC 3' & \multirow{2}{*}{313} \\
\hline $\mathrm{BC} 10$ & & Sense & 5' CTCTGTGTCCTCTTCTTGTG 3' & \\
\hline BC 11 & \multirow{2}{*}{ Rbcl } & Antisense & 5' TACTTGAACGCTACTGCAG 3' & \multirow{2}{*}{186} \\
\hline $\mathrm{BC} 12$ & & Sense & 5' CTGCATGCATTGCACGGTG 3' & \\
\hline
\end{tabular}

*The sequences of primers were taken from Sanchez-Navarro et al. (2005).

DNA polymerase (Bioron, Germany). The reaction was performed with the mixture of the all primer pairs at a final concentration of $6.25 \mathrm{pmol}$ except primers of ApMV (25 pmol) and the internal control the ribulose 1,5-bisphosphatecarboxylase chloroplast (Rbcl) gene (1.25 pmol), containing 1X PCR buffer, $2.5 \mathrm{mM} \mathrm{MgCl}, 0.2 \mathrm{mM}$ dNTPs, 4 mM DTT, 10 U RNAsin (Promega, USA), 10 U MMuLV reverse transcriptase (Biobasic, Canada), 2.5 U Taq DNA polymerase (Bioron, Germany). The MJ Mini thermal cycler PTC1148 (Bio-Rad, USA) was programmed for cDNA synthesis at $42^{\circ} \mathrm{C}$ for $60 \mathrm{~min}$ and for initial denaturation at $94^{\circ} \mathrm{C}$ for $4 \mathrm{~min}$ and then, 40 cycles of denaturation at $94^{\circ} \mathrm{C}$ for $30 \mathrm{~s}$ primer annealing at $50^{\circ} \mathrm{C}$ for $30 \mathrm{~s}$ and primer extension at $72^{\circ} \mathrm{C}$ for $1 \mathrm{~min}$ and for final extension at $72^{\circ} \mathrm{C}$ for $5 \mathrm{~min}$. PCR products were separated in $2 \%$ agarose gel by electrophoresis, stained with ethidium bromide, visualized and photographed by Doc-It gel imaging and documentation system (UVP, England).

Reverse transcription polymerase chain reaction (RTPCR). To confirm the mRT-PCR results, three field samples including one peach sample found to be mixed infected with ApMV, PDV and PRNSV (46), two sweet cherry samples, one found to be mixed infected with PDV and PRNSV (82) and the other found to be infected only with ACLSV (96) in mRT-PCR were selected, RNA isolated was isolated from these samples were tested for presence of ApMV, PDV, PRNSV and ACLSV individually by two step reverse transcription polymerase chain reaction (RTPCR) using PrimeScript RT-PCR kit. About $5 \mu$ of total nucleic acids were denatured at $65^{\circ} \mathrm{C}$ for 5 min and quickly chilled on ice. cDNA was synthesized in $20 \mu \mathrm{l}$ mixture containing 1X PrimeScript buffer, 20 unit RNAsin, $0.5 \mathrm{mM}$ dNTPs, 20 unit PrimeScript and 20 pmol random hexamers using the MJ Mini thermal cycler PTC1148 (Bio-Rad,
USA) programmed as $30^{\circ} \mathrm{C}$ for $10 \mathrm{~min}$. followed by $42^{\circ} \mathrm{C}$ for $60 \mathrm{~min}$ and $75^{\circ} \mathrm{C}$ for $15 \mathrm{~min}$. PCR was conducted in 25 $\mu 1$ reaction mixture of $1 \mathrm{X}$ PCR buffer, $0.2 \mathrm{mM}$ dNTPs, 1.25 unit TaKaRa Ex Taq HS DNA polymerase, $2.5 \mu$ of cDNA and $20 \mathrm{pmol}$ of primer pairs specific to individual viruses (ApMV, PDV, PRNSV or ACLSV) with primers listed in Table 1. PCR was performed in the MJ Mini thermal cycler PTC1148 (Bio-Rad, USA) was programmed for initial denaturation at $94^{\circ} \mathrm{C}$ for $4 \mathrm{~min}$ and then, 40 cycles of denaturation at $94^{\circ} \mathrm{C}$ for $30 \mathrm{~s}$ primer annealing at $50{ }^{\circ} \mathrm{C}$ for $30 \mathrm{~s}$ and primer extension at $72^{\circ} \mathrm{C}$ for $1 \mathrm{~min}$ and for final extension at $72^{\circ} \mathrm{C}$ for $5 \mathrm{~min}$. and PCR products were analyzed as described in the previous section.

\section{Results}

Field surveys. Surveys were conducted in forty-two commercial and three collection orchards in nine different districts of Isparta Province which is the most important stone fruit production areas in western Mediterranean region of Turkey. To represent the different farm types in the region big and small production orchards with old trees as well relatively new orchards established with dwarf and semi-dwarf cherry rootstocks were visited during the surveys. Since sweet cherry was the most commonly grown stone fruit in the region about half of the orchards visited were sweet cherry orchards majority of which were established with local variety 0900 Ziraat. A total of 175 leaf samples were collected from stone fruit trees. More than half of the samples (94) were collected from sweet cherry trees and the remaining samples were consisted of leaf samples collected from peach (38) apricot (27), plum (11) and sour cherry (5). Although sweet cherry samples were collected from different districts, peach and apricot samples were concentrated in Egirdir and Yalvac which are the main peach and apricot 
Table 2. Summary of ELISA tests for five stone fruit viruses on samples collected from commercial and collection orchards in different districts of Isparta regardless of host

\begin{tabular}{|c|c|c|c|c|c|c|c|c|c|c|c|c|c|}
\hline \multirow[b]{2}{*}{ Location } & \multirow[b]{2}{*}{$\begin{array}{c}\text { Total No. of } \\
\text { samples } \\
\text { tested }\end{array}$} & \multicolumn{12}{|c|}{ Number of infected samples } \\
\hline & & ACLSV & ApMV & PDV & PNRSV & PPV & $\begin{array}{c}\text { PDV } \\
+ \\
\text { PNRSV }\end{array}$ & $\begin{array}{c}\text { PDV } \\
+ \\
\text { ACLSV }\end{array}$ & $\begin{array}{c}\text { PDV + } \\
\text { PRNSV + } \\
\text { ACLSV }\end{array}$ & $\begin{array}{c}\text { No. of } \\
\text { Mixed } \\
\text { Infection }\end{array}$ & $\begin{array}{l}\text { Mixed } \\
\text { Infection } \\
\text { rate }(\%)\end{array}$ & $\begin{array}{c}\text { Total } \\
\text { No. of } \\
\text { Infection }\end{array}$ & $\begin{array}{c}\text { Infection } \\
\text { rate }(\%)\end{array}$ \\
\hline Merkez & 21 & 0 & 0 & 10 & 2 & 0 & 0 & 0 & 0 & 0 & 0,0 & 12 & 57,1 \\
\hline Atabey & 28 & 3 & 0 & 5 & 5 & 0 & 0 & 0 & 2 & 2 & 7,1 & 11 & 39,3 \\
\hline Egirdir & 32 & 7 & 0 & 0 & 4 & 0 & 0 & 0 & 0 & 0 & 0,0 & 11 & 34,4 \\
\hline Gelendost & 15 & 4 & 0 & 4 & 0 & 0 & 0 & 0 & 0 & 0 & 0,0 & 8 & 53,3 \\
\hline Gonen & 7 & 1 & 0 & 4 & 1 & 0 & 1 & 0 & 0 & 1 & 14,3 & 5 & 71,4 \\
\hline Keciborlu & 27 & 1 & 0 & 6 & 1 & 0 & 1 & 0 & 0 & 1 & 3,7 & 7 & 25,9 \\
\hline Senirkent & 10 & 2 & 0 & 6 & 1 & 0 & 1 & 1 & 0 & 2 & 20,0 & 7 & 70,0 \\
\hline Uluborlu & 13 & 4 & 0 & 8 & 1 & 0 & 1 & 2 & 0 & 3 & 23,1 & 10 & 76,9 \\
\hline Yalvac & 22 & 2 & 0 & 3 & 1 & 0 & 0 & 0 & 0 & 0 & 0,0 & 6 & 27,3 \\
\hline Total & 175 & 24 & 0 & 46 & 16 & 0 & 4 & 3 & 2 & 9 & 5,1 & 77 & 44,0 \\
\hline \multicolumn{2}{|c|}{ Infection rate $(\%)$} & 13,7 & 0,0 & 26,3 & 9,1 & 0,0 & 2,3 & 1,7 & 1,1 & 5,1 & & 44,0 & \\
\hline
\end{tabular}

growing districts, respectively. A number of samples collected from different Prunus species and their distribution to the districts of Isparta is summarized in Table 2. A number of different virus or virus-like symptoms including local and systemic chlorosis, leaf spots, vein clearing, mosaic, leaf deformation, discoloration and size reduction and various degrees of dwarfing were observed in sweet and sour cherry, peach, apricot and plum trees. Some of these symptoms photographed during field surveys are presented in Figure 1. Observation of the presence of these symptoms indicated that trees in the visited orchards were possibly infected with some stone fruit viruses.

Detection of stone fruit viruses by enzyme linked immunosorbent assay (ELISA). All stone fruit samples were tested separately for ApMV, PNRSV, PDV, PPV,
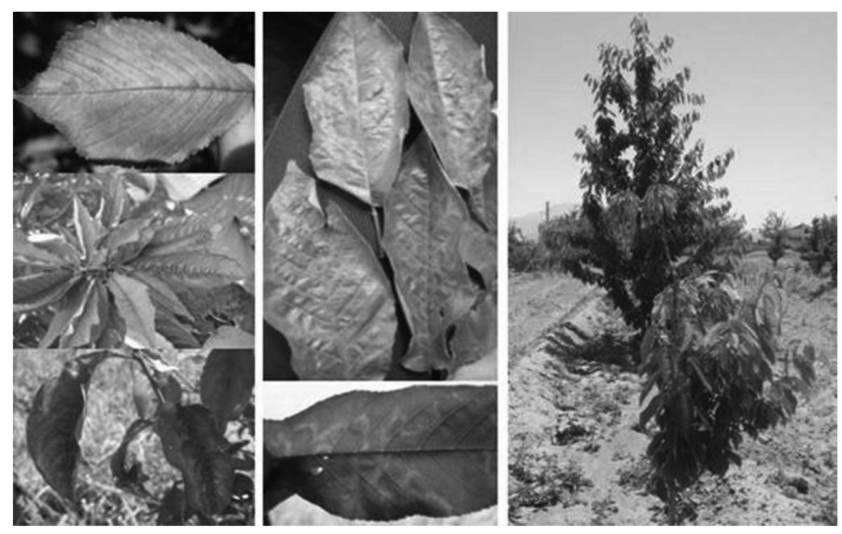

Fig. 1. Symptoms observed in stone fruit trees in commercial orchard during field surveys.
ACLSV using commercially available DAS-ELISA kits with negative and positive controls for each virus. The results showed that 77 of 175 stone fruit samples evaluated by DAS-ELISA found to be infected with at least one of the five viruses tested indicating that about half (44\%) of symptomatic samples collected from stone fruit orchards were infected with viruses. While none of the samples were infected with ApMV and PPV, 46, 24 and 16 symptomatic samples were infected with PDV, ACLSV and PNRSV, respectively. The results revealed that with an infection rate of $26.3 \%$ PDV was the most widespread virus in symptomatic trees in stone fruit orchards in western Mediterranean region of Turkey (Table 2).

When the distributions of these viruses on different symptomatic hosts were evaluated, it was found that ACLSV was most commonly detected in peach samples with an infection rate of $26.3 \%$ followed by sour cherry, apricot, sweet cherry and plum with an infection rate of 20.0, 11.1, 9.6 and $9.1 \%$, respectively. Only one sour cherry and plum samples were infected with ACLSV, however, due to small sample size the infection rate of ACLSV looked higher in sour cherry and plums (Table 2). ACLSV was detected in different stone fruit samples from all districts except Merkez, but the highest infection rate was observed in Uluborlu districts where about $30 \%$ of symptomatic sweet cherry trees were tested ACLSV positive. PNRSV was not detected on apricot but it was most commonly detected in sour cherry samples with an infection rate of $20 \%$ followed by symptomatic peach, plum and sweet cherry with an infection rate of 15.0, 9.1 and $8.5 \%$ of respectively. Although the highest infection rate with PNRSV was observed in sour cherry, only one sour cherry sample was 


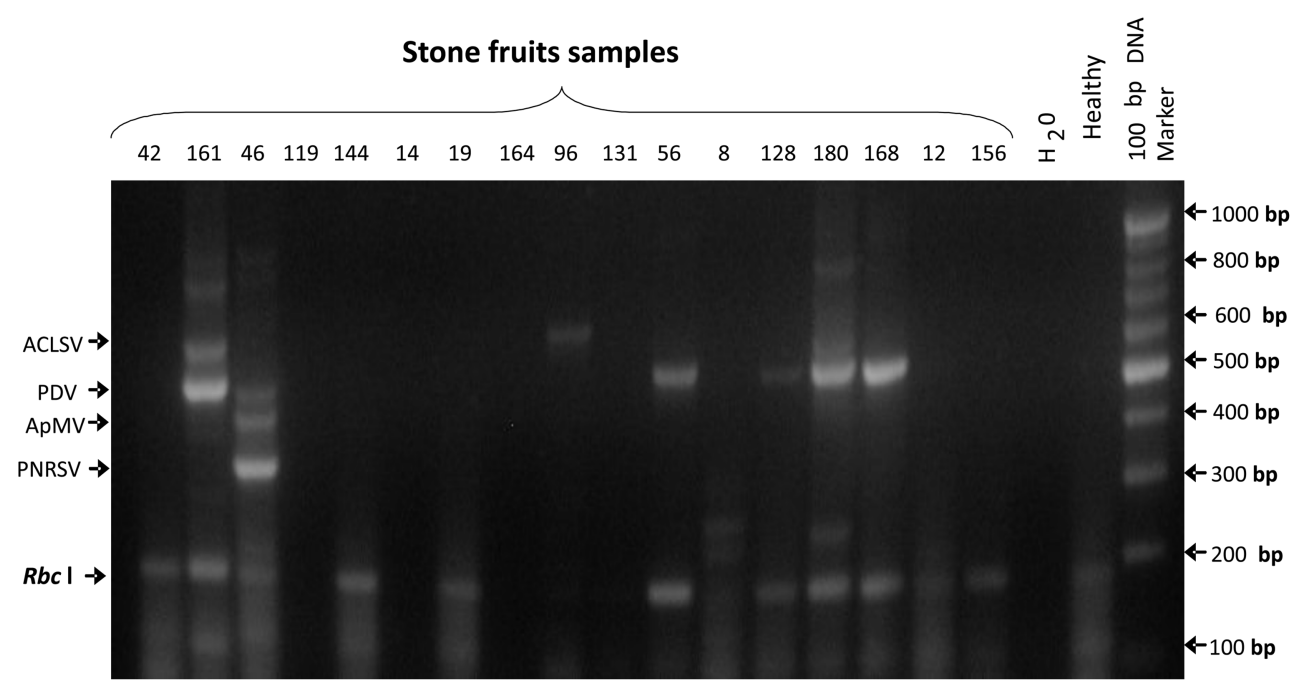

Fig. 2. Multiplex RT-PCR assay for detection of five different RNA viruses on different Prumus host samples. Rbc1 is the ribulose 1,5bisphosphatecarboxylase chloroplast (Rbcl) gene used as control. DNA fragment corresponding to individual viruses indicated by arrow. $\mathrm{H}_{2} \mathrm{O}$ : no RNA added used as negative control.

infected with this virus. Actually the highest number of PNRSV infected samples (8) was found in sweet cherry (Table 2). PNRSV was detected in different stone fruit samples collected from all districts except Gelendost but the highest infection rate was observed in Atabey district where about $18 \%$ of symptomatic samples were tested PNRSV positive (Table 2).

No PDV was detected on sour cherry and plum and only one peach and two apricot samples were infected with PDV resulting 2.6 and $7.5 \%$ infection rate in these plants, respectively. On the other hand, $45.7 \%$ of symptomatic sweet cherry samples tested were PDV positive revealing that PDV was the most widespread virus and largely associated with sweet cherry. PDV was detected in different stone fruit samples collected from all districts except Egirdir but the highest infection rate was observed in Uluborlu and Senirkent district where more than $30 \%$ of symptomatic samples were tested PDV positive (Table 2).

ELISA test also showed the presence of mixed infection with more than one virus in Isparta region. From 77 samples tested positive in ELISA, nine of them were mixed infected with two or three different viruses resulting 5.1\% mixed infection in symptomatic stone fruit samples. All mixed infected samples were from sweet cherry and these samples contained double infection with PDV and PNRSV or PDV and ACLSV or triple infection with PDV, PNRSV and ACLSV (Table 2). Mixed infections were found in 5 out of 9 districts but the highest mixed infection rate was observed in Uluborlu and Senirkent districts where more than $20 \%$ of symptomatic samples were infected with different viruses simultaneously (Table 2).

With an infection rate of $54.3 \%$ in symptomatic trees, sweet cherry was the most frequently infected plant among five Prunus species tested followed by peach, sour cherry, apricot and plum with an infection rate of 44.7, 40, 18.5 and 18.2, respectively. While sweet cherry trees were largely infected with PDV, sour cherry, peach and plum trees were mainly infected with ACLSV and PNRSV. On the other hand ACLSV and PDV were prevailing viruses in apricot (Table 2).

Detection of stone fruit viruses by mRT-PCR assay. A previously developed multiplex RT-PCR assay for simultaneous detection of eight different stone fruit viruses (Sanchez-Navarro et al., 2005) was modified by excluding three viruses and was used for detection of five different RNA viruses on stone fruits growing in western Mediterranean region of Turkey. A total of 30 samples tested by ELISA for the presence of five different viruses were selected to represent all different regions and hosts of stone fruit samples collected. Viral RNA was isolated from leaf samples of symptomatic trees by two previously reported methods (Astruc et al., 1996; Morris and Dodds, 1979). While RNA isolated by both methods was used for mRT-PCR assays, RNA from dsRNA isolation method gave more consistent results in mRT-PCR assay. Therefore, mRT-PCR tests were conducted using RNA from dsRNA isolation method. RNA isolated from 30 samples were tested by mRT-PCR assay for detection of ACLSV, PDV, ApMV, PNRSV and PPV by amplification of 632 bp, 517 bp, 417 bp, 346 bp 313 bp DNA fragment respectively, with $186 \mathrm{bp}$ fragment of the ribulose 1,5-bisphosphate carboxylase chloroplast (Rbc1) gene as the internal control (Sanchez-Navarro et al., 2005). Using one step mRT-PCR 
Table 3. Summary of ELISA tests for five stone fruit viruses on different Prunus host samples collected from commercial and collection orchards regardless of location

\begin{tabular}{|c|c|c|c|c|c|c|c|c|c|c|c|c|c|}
\hline \multirow[b]{2}{*}{ Location } & \multirow{2}{*}{$\begin{array}{c}\text { No. of } \\
\text { Samples } \\
\text { Tested }\end{array}$} & \multicolumn{8}{|c|}{ Number of Infected Samples } & \multirow{2}{*}{$\begin{array}{l}\text { No. of } \\
\text { Mixed } \\
\text { Infection }\end{array}$} & \multirow{2}{*}{$\begin{array}{c}\text { Mixed } \\
\text { Infection } \\
\text { Rate }(\%)\end{array}$} & \multirow{2}{*}{$\begin{array}{l}\text { Total No. } \\
\text { of Infec- } \\
\text { tion }\end{array}$} & \multirow[b]{2}{*}{$\begin{array}{l}\text { Infection } \\
\text { Rate (\%) }\end{array}$} \\
\hline & & ACLSV & PDV & PNRSV & ApMV & PPV & $\begin{array}{c}\text { PDV + } \\
\text { PNRSV }\end{array}$ & $\begin{array}{l}\text { PDV + } \\
\text { ACLSV }\end{array}$ & $\begin{array}{c}\text { PDV+ } \\
\text { PRNSV + } \\
\text { ACLSV }\end{array}$ & & & & \\
\hline Sweet Cherry & 94 & 9 & 43 & 8 & 0 & 0 & 4 & 3 & 2 & 9 & 9,6 & 60 & 54,3 \\
\hline Sour Cherry & 5 & 1 & 0 & 1 & 0 & 0 & 0 & 0 & 0 & 0 & 0,0 & 2 & 40,0 \\
\hline Peach & 38 & 10 & 1 & 6 & 0 & 0 & 0 & 0 & 0 & 0 & 0,0 & 17 & 44,7 \\
\hline Apricot & 27 & 3 & 2 & 0 & 0 & 0 & 0 & 0 & 0 & 0 & 0,0 & 5 & 18,5 \\
\hline Plum & 11 & 1 & 0 & 1 & 0 & 0 & 0 & 0 & 0 & 0 & 0,0 & 2 & 18,2 \\
\hline Total & 175 & 24 & 46 & 16 & 0 & 0 & 4 & 3 & 2 & 9 & 5,1 & 86 & 49,1 \\
\hline \multicolumn{2}{|c|}{ Infection rate $(\%)$} & 13,7 & 26,3 & 9,1 & 0,0 & 0,0 & 2,3 & 1,7 & 1,1 & 5,1 & & 49,1 & \\
\hline
\end{tabular}

assay, DNA fragments specific to 4 out of 5 RNA viruses (ACLSV, ApMV, PNRSV and PDV) were detected on stone fruit samples (Fig. 2). The mRT-PCR assay showed that none of the samples tested positive with PPV indicating that PPV, is not present commercial stone fruit orchards in the region. It was determined by mRT-PCR that 19, 4, 3, 1 samples were infected with PDV, ACLSV, PNRSV and ApMV, respectively. Based on mRT-PCR results of the tested samples the infection rate of PDV, ACLSV, PNRSV and ApMV was 63, 13, 10 and 3.3\% respectively (Table 3).

Detection of stone fruit viruses individually by RT-PCR Assay. The results of mRT-PCR were confirmed by detection of individual viruses by RT-PCR. For this purpose three field samples including one peach sample found to be mixed infected with ApMV, PDV and PRNSV (46), two sweet cherry samples one found to be mixed infected with
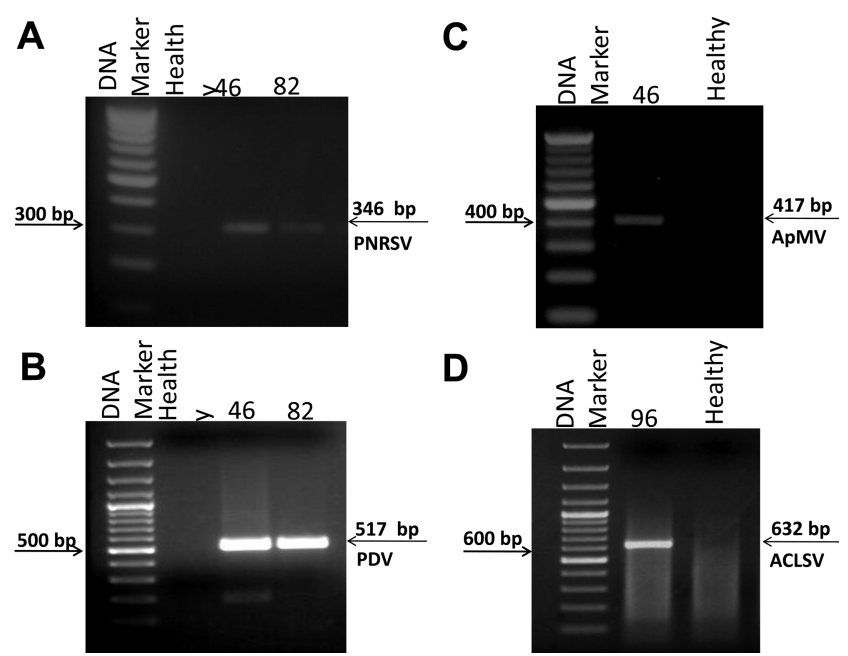

Fig. 3. RT-PCR assay for individual detection of (A) Prunus necrotic ringspot ilarvirus (PNRSV), (B) Prune dwarf ilarvirus (PDV), (C) Apple mosaic ilarvirus (ApMV) (D) Apple chlorotic leafspot trichovirus (ACLSV)
PDV and PRNSV (82) and the other found to be infected only with ACLSV (96) in mRT-PCR, were tested for the presence of specific viruses individually. RT-PCR test for single virus detection showed that individual bands about 346, 417, and 517 bp corresponding amplicon of PRNSV, ApMV and PDV, respectively, were amplified from sample 46 using primers specific to each virus (Fig. 3a, b and c). Similarly DNA fragments of about 346 and 517 bp specific to PRNSV and PDV, respectively, were amplified individually from sample 82 using primer specific to these viruses (Fig. $3 \mathrm{a}, \mathrm{b}$ and c). Only a band of about $634 \mathrm{bp}$ corresponding to ACLSV was amplified from the sample 96 by ACLSV specific primers (Fig. 3d). However, no DNA fragment was amplified from healthy control samples using the same primer sets and RT-PCR conditions (Fig. 3a-d). The results of RT-PCR experiments for individual viruses demonstrated that the band in the same size as the ones detected in mRTPCR of the same samples were amplified by virus specific primers individually confirming that bands produced in mRT-PCR were virus specific cDNA fragments rather than PCR artifacts.

Comparison of ELISA and mRT-PCR Assay. To evaluate sensitivity and usefulness of two different detection methods, the results obtained from ELISA assay for five different viruses were compared with the results of mRT-PCR assay for the same samples (Table 3). In ELISA, 175 symptomatic samples were tested and only three (PDV, ACLSV, and PNRSV) of the five viruses were detected on the other hand four (ACLSV, PNRSV, PDV and ApMV) of the five viruses were detected from only 30 symptomatic samples by mRT-PCR. Among the 30 samples tested by two assays 14 of them were positive with one of the three viruses, but number of samples infected with the same viruses was increased by six and reached to 20 in mRT-PCR assay. When the ELISA and mRT-PCR results of the same samples were compared one by one, it was found that only 
Table 4. Comparison of the results of ELISA and multiplex RT-PCR methods used for detection of five stone fruit viruses on different Prunus host samples collected from commercial and collection orchards in different districts of Isparta

\begin{tabular}{|c|c|c|c|c|c|c|c|c|c|c|c|c|}
\hline \multirow{2}{*}{$\begin{array}{c}\text { Sample } \\
\text { No }\end{array}$} & \multirow{2}{*}{ Location } & \multirow{2}{*}{ Host* } & \multicolumn{2}{|c|}{ ACLSV } & \multicolumn{2}{|c|}{ ApMV } & \multicolumn{2}{|c|}{ PDV } & \multicolumn{2}{|c|}{ PNRSV } & \multicolumn{2}{|c|}{$\begin{array}{l}\text { PPV } \\
\end{array}$} \\
\hline & & & ELISA & RT-PCR & ELISA & RT-PCR & ELISA & RT-PCR & ELISA & RT-PCR & ELISA & RT-PCR \\
\hline 8 & Eğirdir & Apricot & - & - & - & - & - & - & - & - & - & - \\
\hline 12 & Eğirdir & Peach & - & - & - & - & - & - & + & - & - & - \\
\hline 14 & Eğirdir & Cherry & - & - & - & - & - & - & - & - & - & - \\
\hline 19 & Eğirdir & Plum & - & - & - & - & - & - & - & - & - & - \\
\hline 25 & Eğirdir & Peach & + & - & - & - & - & + & - & - & - & - \\
\hline 40 & Atabey & Peach & - & - & - & - & - & + & - & - & - & - \\
\hline 42 & Merkez & Cherry & - & - & - & - & - & - & - & - & - & - \\
\hline 46 & Merkez & Peach & - & - & - & + & + & + & - & + & - & - \\
\hline 53 & Merkez & Cherry & - & - & - & - & + & + & - & - & - & - \\
\hline 56 & Merkez & Cherry & - & - & - & - & + & + & - & - & - & - \\
\hline 59 & Merkez & Cherry & - & - & - & - & + & + & - & - & - & - \\
\hline 73 & Atabey & Peach & - & - & - & - & - & + & - & - & - & - \\
\hline 76 & Egirdir & Peach & - & - & - & - & - & + & - & - & - & - \\
\hline 77 & Uluborlu & Cherry & - & + & - & - & - & + & - & - & - & - \\
\hline 82 & Senirkent & Cherry & - & - & - & - & + & + & + & + & - & - \\
\hline 84 & Uluborlu & Cherry & - & - & - & - & + & + & + & + & - & - \\
\hline 96 & Senirkent & Cherry & - & + & - & - & - & - & - & - & - & - \\
\hline 113 & Gelendost & Peach & - & - & - & - & - & + & - & - & - & - \\
\hline 119 & Atabey & Cherry & - & - & - & - & - & - & - & - & - & - \\
\hline 120 & Atabey & Peach & - & - & - & - & - & + & - & - & - & \\
\hline 125 & Atabey & S.Cherry & + & - & - & - & - & - & - & - & - & - \\
\hline 128 & Yalvaç & Apricot & - & - & - & - & + & + & - & - & - & - \\
\hline 131 & Yalvaç & Cherry & - & - & - & - & - & - & - & - & - & - \\
\hline 144 & Yalvaç & Apricot & - & - & - & - & - & - & - & - & - & - \\
\hline 156 & Gönen & Cherry & - & - & - & - & + & + & - & - & - & - \\
\hline 161 & Keçiborlu & Cherry & - & + & - & - & + & + & + & - & - & - \\
\hline 164 & Keçiborlu & Cherry & - & - & - & - & - & - & - & - & - & - \\
\hline 168 & Keçiborlu & Cherry & - & - & - & - & + & + & - & - & - & - \\
\hline 173 & Keçiborlu & Cherry & - & + & - & - & + & + & - & - & - & - \\
\hline 180 & Atabey & Cherry & - & - & - & - & - & + & - & - & - & - \\
\hline \multirow{2}{*}{\multicolumn{3}{|c|}{$\begin{array}{l}\text { Total Number of Positive } \\
\text { Infection Rate }(\%)\end{array}$}} & 2 & 4 & 0 & 1 & 11 & 19 & 4 & 3 & 0 & 0 \\
\hline & & & 6,7 & 13,3 & 0 & 3,3 & 36,7 & 63,3 & 13.3 & 10 & 0 & 0 \\
\hline & & & & ELISA & \multicolumn{2}{|c|}{ RT-PCR } & & & & & ELISA & RT-PCR \\
\hline \multicolumn{4}{|c|}{ Total Number of Infected Samples } & 14 & \multicolumn{2}{|c|}{20} & \multicolumn{4}{|c|}{ Total Number of Mix Infected Samples } & 3 & 5 \\
\hline \multicolumn{4}{|c|}{ Total Infection Rate (\%) } & 46,7 & \multicolumn{2}{|c|}{66,7} & \multicolumn{4}{|c|}{ Total Mixed Infection Rate (\%) } & 10 & 16,7 \\
\hline
\end{tabular}

*Cherry: Sweet cherry and S.Cherry: Sour cherry

four of the samples tested negative in mRT-PCR assay were tested positive in ELISA (Table 3). This could result from false positive reaction in ELISA or poor recovery during nucleic acid isolation since internal control Rbc1 was not amplified from these samples. On the other hand more than 10 samples tested negative in ELISA gave positive reaction in mRT-PCR assay. Considering only 30 samples were tested by mRT-PCR this number can significantly be increased if more samples were tested. It was found that the rate of infection with these viruses were 46.7 and $66.7 \%$ in ELISA and mRT-PCR, respectively, in the same group of sympto- matic samples (Table 3) indicating that mRT-PCR is more sensitive method than ELISA for detection of these viruses.

\section{Discussion}

Serological and molecular assays revealed that four of the five viruses including ApMV, ACLSV, PNRSV and PDV were present in the region. Sweet cherry being the most commonly grown stone fruit in the region had the highest infection rate $(54.3 \%)$ in symptomatic trees. While PDV most commonly associated with symptomatic sweet cherry 
trees, ACLSV and PNRSV were mostly found in symptomatic peach trees. Although a few sweet cherry samples showed a week reaction with PPV antiserum in ELISA, these samples were considered negative since results were not confirmed by RT-PCR. PPV has been present in Turkey for some time but it was contained in certain regions and mainly detected in home gardens. With the exception of Bursa main stone fruit production regions of Turkey were free of PPV (Sipahioglu et al., 1999; Elibuyuk, 2003; Elibuyuk, 2004). This study showed that PPV is excluded in commercial orchards in the region. Total exclusion of PPV in the region could be due to the use of local varieties, certified propagation materials and quarantine. PPV has not been reported on sweet cherry in Turkey and it is not commonly associated with sweet cherry trees in main production regions of the world. Since sweet cherry is the main stone fruit growing in the region, more than half of the symptomatic samples tested in this study were collected from sweet cherry. Therefore, absence of PPV in the region may be explained by testing small number of samples from peach, plum and apricots to which PPV is most commonly associated.

Among the viruses detected in this study ApMV was previously detected only on apple trees (Yardimci and Eryigit 2005) in the region but it has not been reported on stone fruits. ACLSV and PNRSV were previously detected in a few trees in a collection orchard (Ulubas and Ertunc, 2004; Ulubas and Ertunc, 2005). However, PDV was not previously detected in any fruit crop in the region and detected first time on stone fruits in the region by ELISA and mRTPCR. Therefore, this study presents the first report of ApMV, and PDV stone fruits and all four viruses in commercial stone fruit orchards in the western Mediterranean region of Turkey.

The finding of this study revealed that about the half of the stone fruit trees were infected with one or more viruses including ApMV, ACLSV, PNRSP and PDV. Detection of these viruses on stone fruit orchards (Elibuyuk, 2003; Elibuyuk and Erdiler, 1998; Gazel and Caglayan, unpublished data; Sipahioglu et al., 1999; Sipahioglu and Baloglu, unpublished data; Yildizgordu and Calli, 1994) and nurseries (Azeri, unpublished data; Ulubas and Ertunc, 2004; Sertkaya et al., 2004) in different regions of Turkey indicates that they likely to be introduced into the region by infected plant propagation materials. The rate of infection in symptomatic trees ranged from 0 to $46 \%$ in ELISA and from 3.3 to $63 \%$ in RT-PCR. The infection rate of all viruses except PPV obtained in this study in symptomatic trees was similar with similar study covering the same viruses in Aegean region (Azeri, 1994). However, the infection rate of symptomatic trees with four viruses, especially PDV was higher than previous studies covering some of the same viruses in stone fruits in eastern Mediterranean (Gazel and Caglayan, unpublished data; Yildizgordu and Cali, unpublished data) and eastern Anatolian region (Elibuyuk and Erdiler 1998; Sipahioglu et al., 1999; Sipahioglu and Baloglu, unpublished data). Aegean and western Mediterranean regions are geographically closer to each other than other regions, thus similar infection rate with all five viruses except PPV observed in both region is likely due to exchange of infected propagation material between these regions. With the infection rate of 46 and $63 \%$ observed in symptomatic trees in ELISA and mRT-PCR assays, PDV was the most frequently found virus tested in this study. This was consistent with the result obtained from a ten year surveys in stone fruits in different Mediterranean countries (Mytra et al., 2003) confirming that as in other stone fruit growing regions of other Mediterranean countries PDV was the most widespread virus in western Mediterranean region of Turkey.

Mixed infections of two or more viruses were frequently detected on stone fruits in different region of the world (Dominguez et al., 1998; Mytra et al., 2003; Varveri and Bem, 1995). In this study, $5.1 \%$ of the symptomatic samples tested in ELISA were mixed infected with combination of PDV, ACLSV and PRNSV. Mixed infection rate observed in symptomatic trees in this study, especially in sweet cherry, was higher than other regions of Turkey (Azeri, unpublished data) but much lower than the other Mediterranean countries (Mytra et al., 2003). Although mixed infections were only detected in symptomatic sweet cherry in ELISA, mixed infections were detected in other hosts such as peach in mRT-PCR suggesting that mixed infection rate in is probably much higher.

Biological, serological and molecular assays have generally been used for identification of stone fruits viruses. Although ELISA is the preferred assay for routine virus detection, RT-PCR has increasingly been used for detection and identification of viruses due to higher level of sensitivity (Herranz et al., 2005; Pallas et al., 1998; SanchezNavaro et al., 1998; Saade et al., 2000). Development of mRT-PCR enabling detection of more than one virus simultaneously on fruit trees significantly reduced the time, labor and cost of RT-PCR (Hassan et al., 2006; Menzel et al., 2002; Sanchez-Navaro et al., 2005). Therefore we have modified and used a mRT-PCR assay developed for detection of stone fruit viruses (Sanchez-Navaro et al., 2005) to assess the sensitivity and applicability of mRT-PCR for detection of five different viruses in naturally infected trees. Testing same group of samples by ELISA and mRT-PCR it was shown that more viruses, infection and mixed infection were detected by mRT-PCR than ELISA assay for multiple viruses. Results of this study in agreement with previous studies showing higher sensitivity of RT-PCR and confirms 
the sensitivity, reliability and applicability of mRT-PCR previously reported for stone fruits (Sanchez-Navaro et al., 1998; Saade et al., 2000; Sanchez-Navaro et al., 2005).

Sanitary status of stone fruit orchard was determined by detection of five RNA viruses commonly infecting stone fruits $\mathrm{s}$ in the western Mediterranean region of Turkey. The results showed ApMV, ACLSV, PDV and PNRSP were present, but no PPV infection was tested in the region. Infection rate of $44 \%$ and $66.7 \%$ observed in symptomatic trees by ELISA and mRT-PCR assays showed that at least more than $40 \%$ of the symptomatic trees were infected with one or more of these viruses. This study also presents the first report of detection ApMV, and PDV in stone fruits in the western Mediterranean region of Turkey.

\section{Acknowledgments}

This study was supported by Suleyman Demirel University Research Found Grant 1067-M-05 to B. Cevik. Authors thank to Local Extension Agents of Ministry of Agriculture and Suat Kaymak from Egirdir Horticulture Research Institute for their help during field surveys and Gozde Erklis, Guliz Tepedelen and Erdem Aksan for their technical assistance.

\section{References}

Astruc, N., Marcos, J. F., Macquaire, G, Candresse, T. and Pallás, V. 1996. Studies on the diagnosis of hop stunt viroid in fruit trees: identification of new hosts and application of a nucleic acid extraction procedure based on non-organic solvents. Euro. J. Plant Pathol. 102:837-846.

Clark, M. F. and Adams, A. N. 1977. Characteristics of the microplate method of enzyme linked immunosorbent assay for the deduction plant viruses. J. Gen. Virol. 340:475-483.

Dominguez, S., Aparicio, F., Sanchez-Navarro, J. A., Cano, A., Garcia-Brunton, J. and Pallas V. 1998. Studies on the incidence of ilarviruses and apple chlorotic leaf spot virus (ACLSV) in apricot trees in the Murcia region (Spain) using serological and molecular hybridisation methods. Acta Hort. 472:203-210.

Dunez, J. 1988. Fruit crop Sanitation in the Mediterranean and Near East Region. United Nations Development Programme. FAO.

Elibuyuk, I. O. 2003. Natural spread of Plum pox virus in Ankara, Turkey. J. Phytopathol. 151:617-619.

Elibuyuk, I. O. 2004. Current situation of sharka disease in Ankara, Turkey. Phytoparasitica 32:417-420.

Hassan, M., Myrta, A. and Polak, J. 2006. Simultaneous detection and identification of four pome fruit viruses by one-tube pentaplex RT-PCR. J. Virol. Methods 133:124-129.

Herranz, M. C., Sanchez-Navarro, J. A., Aparicio, F. and Pallas, V. 2005. Simultaneous detection of six stone fruit viruses by non-isotopic molecular hybridization using a unique riboprobe or 'polyprobe'. J. Virol. Methods 124:49-55.

Menzel, W., Jelkmann, W. and Maiss, E. 2002: Detection of four apple viruses by multiplex RT-PCR assays with coamplification of plant mRNA as internal control. J. Virol. Methods 99:81-92.

Morris, T. J. and Dodds, J. A. 1979. Isolation and analysis of double-stranded RNA from virus infected plant and fungal tissue. Phytopathology 69:854-858.

Myrta, A., Di Terlizzi, B., Savino, V. and Martelli, G. P. 2003. Virus diseases affecting the Mediterranean stone fruit industry: a decade of surveys. In: Option Mediterraneennes, Ser. B/n 45-Virus and Virus-like Diseases of Stone Fruits, with Particular Reference to the Mediterranean Region, pp. 15-23.

Nemeth, M. 1986. Viruses, mycoplasma and rickttsia diseases of fruit trees. Kluwer Academic Publishers, Boston.

Pallas, V. Sanchez-Navarro, J. A. and Canizares, M. C. 1998. Molecular diagnostic techniques and their potential role in stone fruit certification schemes. In: Di Terlizzi, B., Myrta, A. and Savino, V. (eds.). Option Mediterraneennes, Ser. B/n 19. Stone fruit viruses and certification in the Mediterranean countries: problems and prospects. pp. 191-208.

Saade, M., Aparicio, F., Sanchez-Navarro, J., Herranz, M. C., Myrta, A., Di Terlizzi, B. and Pallas, V. 2000. Simultaneous detection of the three ilarviruses affecting stone fruit trees by nonisotopic molecular hybridization and multiplex reversetranscription polymerase chain reaction. Phytopathology 90:1330-1336.

Sanchez-Navarro, J. A., Aparicio, F., Rowhani, A. and Pallas, V. 1998. Comparative analysis of ELISA, nonradioactivemolecular hybridisation and PCR for the detection of prunus necrotic ringsport virus in herbaceous and Prunus hosts. Plant Pathol. 47:780-786.

Sanchez-Navarro, J. A., Aparicio, F., Herranz, M., Minafra, C., Myrta, A. and Pallas, V. 2005. Simultaneous detection and identification of eight stone fruit viruses by one-step RT-PCR. Eur. J. Plant Pathol. 111:77-84.

Sertkaya, G, Caglayan, K. and Ulubas, C. 2004. Detection of some viruses of stone fruits in mother plant blocks in eastern Mediterranean region of Turkey. Acta Hort. 657:127-132.

Sipahioglu, H. M., Myrta, A., Abou-Ghanem, N., Di Terlizzi, B. and Savino V. 1999. Sanitary status of stone fruit trees in East Anatolia (Turkey) with particular reference to apricot. EPPO Bulletin 29:439-442.

Ulubas, C. and Ertunc, F. 2004. RT-PCR detection and molecular characterization of Prumus necrotic ringspot virus isolates occurring in Turkey. J. Phytopath. 152:498-502.

Ulubas, C. and Ertunc, F. 2005. Apple chlorotic leaf spot virus (ACLSV) status in Turkey and sensitive detection using advanced techniques. Turkish J. Agri. Forestry 29:251-257.

Varveri, C. and Bem, F. 1995. Viruses of stone and pome-fruit mother-tree plantations in Greece. Acta Hort. 386:431-438.

Yardimci, N. and Eryiit, H. 2005. New record of Apple mosaic virus on apple cultivars in south-west Turkey. Australasian Plant Pathol. 34:603. 